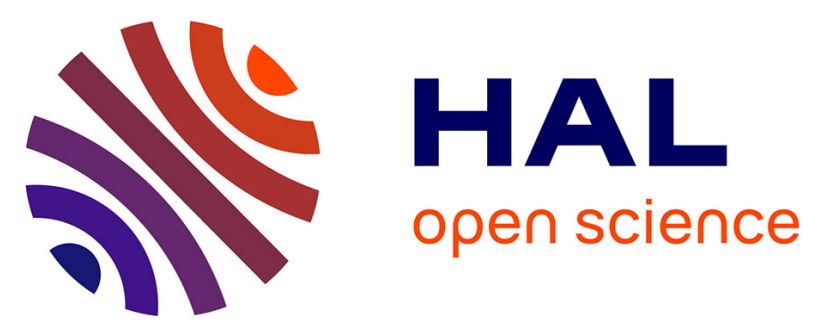

\title{
Lacustrine charcoal peaks provide an accurate record of surface wildfires in a North European boreal forest
}

\author{
Gwenaël Magne, Benoit Brossier, Emmanuel Gandouin, Laure Paradis, Igor
}

Drobyshev, Alexander Kryshen, Christelle Hély, Samuel Alleaume, Adam Ali

\section{- To cite this version:}

Gwenaël Magne, Benoit Brossier, Emmanuel Gandouin, Laure Paradis, Igor Drobyshev, et al.. Lacustrine charcoal peaks provide an accurate record of surface wildfires in a North European boreal forest. The Holocene, 2020, 30 (3), pp.380-388. 10.1177/0959683619887420 . hal-02382756

\section{HAL Id: hal-02382756 https://hal.science/hal-02382756}

Submitted on 25 Feb 2020

HAL is a multi-disciplinary open access archive for the deposit and dissemination of scientific research documents, whether they are published or not. The documents may come from teaching and research institutions in France or abroad, or from public or private research centers.
L'archive ouverte pluridisciplinaire $\mathbf{H A L}$, est destinée au dépôt et à la diffusion de documents scientifiques de niveau recherche, publiés ou non, émanant des établissements d'enseignement et de recherche français ou étrangers, des laboratoires publics ou privés. 


\title{
Lacustrine charcoal peaks provide an accurate record of surface wildfires in a North European boreal forest
}

\author{
Gwenaël Magne, ' D Benoît Brossier,' Emmanuel Gandouin, 2 \\ Laure Paradis, ' Igor Drobyshev, ${ }^{3,4,5}$ Alexander Kryshen, ${ }^{5}$ \\ Christelle Hély, ${ }^{1,6}$ (D) Samuel Alleaume ${ }^{7}$ (D) and Adam A Ali'
}

\begin{abstract}
We evaluated the skills of different palaeofire reconstruction techniques to reconstruct the fire history of a boreal landscape (Russian Karelia) affected by surface fires. The analysis of dated lacustrine sediments from two nearby lakes was compared with independent dendrochronological dating of fire scars, methods which have rarely been used in context of surface fires. We used two sediment sub-sampling volumes (I and $3.5 \mathrm{~cm}^{3}$, wet volumes) and three methods of calculating the Charcoal Accumulation Rate to reconstruct fire histories: CHAR number, charcoal surface area and estimated charcoal volume. The results show that palaeofire reconstructions obtained with fossil charcoal data from lake sediments and dendrochronology are similar and complementary. Dendrochronological reconstruction of fire scars established 12 fire dates over the past 500 years, and paleo-data from lake sediments identified between 7 and 13 fire events. Several 'false fire events' were also recorded in the charcoal chronologies, likely because of errors associated with the estimation of the sediment accumulation rate in the unconsolidated part of the sediment. The number of replicates, that is, number of sub-samples and lakes analyzed, had an effect on the number of identified fire events, whereas no effect was seen in the variation in the analyzed sediment volume or the choice of the charcoal-based metric. Whenever possible, we suggest the use of the dendrochronological data as an independent control for the calibration of charcoal peak series, which helps provide more realistic millennia-long reconstruction of past fire activity. We also argue for the use of $\mathrm{I} \mathrm{cm}^{3}$ sample volume, a sampling protocol involving sampling of more than one lake, and sufficient number of intra-sample replicates to achieve skilful reconstructions of past fire activity.
\end{abstract}

\section{Keywords}

dated fire scar, dendrochronology, lacustrine sediments, late Holocene, natural disturbance regimes, Russian Karelia, surface fires, tree-ring records

Received 20 February 2019; revised manuscript accepted 30 August 2019

\section{Introduction}

Circumboreal forest accounts for almost $30 \%$ of the forest area of our planet, and its dynamics are mostly driven by wildfires (Bowman et al., 2009; Payette, 1992; Van Wagner, 1983). Boreal wildfires burn between 5 and 20 million hectares annually (De Groot et al., 2013), have an impact on the global carbon cycling (this biome contains nearly $32 \%$ of terrestrial global carbon; Pan et al., 2011), and pose tangible short- and long-term risks for local societies and socio-economic activities. As drought severity controls wildfire activity, climate change will likely affect the future fire frequency (De Groot et al., 2013). Understanding the interactions between climate and fire activity across different temporal and spatial scales is of paramount importance to mitigate socio-economic impacts of climate changes (Schreier et al., 2015; Wotton et al., 2010), so it is important to look at the fire dynamics that have affected boreal forest in the past. To reconstruct these fire histories, there are different paleoecological methods that we evaluate in this study.

Lacustrine charcoal records have been commonly used to reconstruct the past variability of fire activity (Flannigan et al., 2008; Gavin et al., 2007; Remy et al., 2018) and to examine climate-fire feedbacks on a decadal resolution over the past millennia. However, reconstruction of past fire activity from sediment charcoal is not a straightforward exercise. The amount of charcoal deposited in a sediment layer is a function of several taphonomic processes controlling the production of charcoal particles, their transportation and sequestration into sediments. These include aerial and ground transport, fragmentation, and re-deposition following particle re-mobilization from soil layers (e.g. Higuera et al., 2010; Lynch et al., 2004; Oris et al., 2014). For the late

\footnotetext{
'Institut des Sciences de l'Evolution de Montpellier (ISEM), Université de Montpellier, CNRS, EPHE, IRD, France

${ }^{2}$ Aix Marseille Université, Avignon Université, CNRS, IRD, IMBE, France ${ }^{3}$ Southern Swedish Forest Research Centre, Swedish University of Agricultural Sciences, Sweden

${ }^{4}$ Institut de recherche sur les forêts, Université du Québec en AbitibiTémiscamingue, Canada

${ }^{5}$ Forest Research Institute of the Karelian Research Centre of the Russian Academy of Sciences, Russia

${ }^{6} \mathrm{EPHE}, \mathrm{PSL}$ University, France

${ }^{7}$ TETIS, IRSTEA, AgroParisTech, CIRAD, CNRS, Université de

Montpellier, France
}

\section{Corresponding author:}

Gwenaël Magne, Institut des Sciences de l'Evolution de Montpellier (ISEM), Université de Montpellier, CNRS, IRD, EPHE, Place Eugène Bataillon, 34095 Montpellier, France.

Email: gwenael.magne@umontpellier.fr 

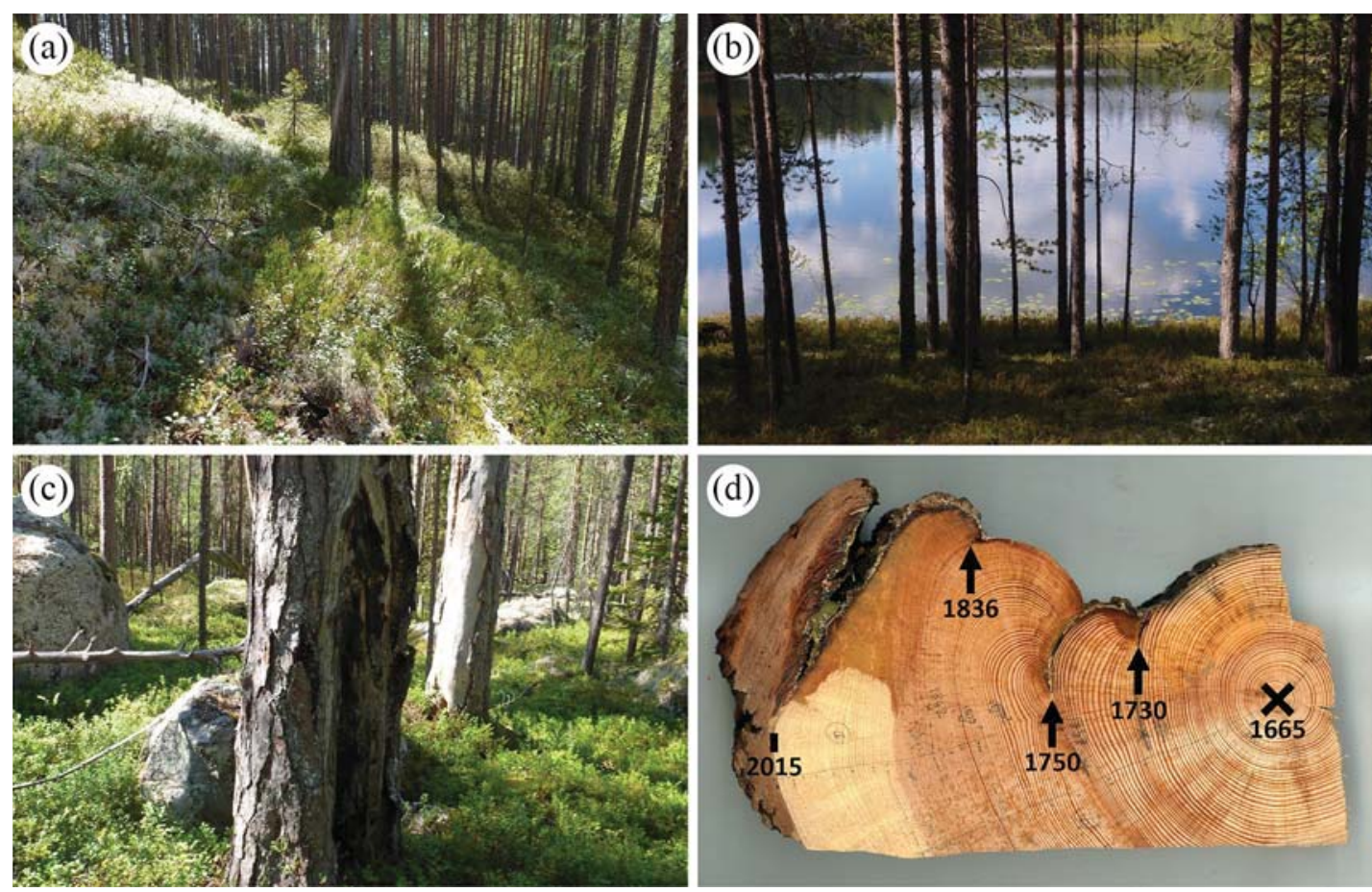

Figure I. (a) Ground vegetation around Gingko and Laure lakes. (b) Pinus sylvestris on the shore of Lake Laure. (c) Fire scar on a Pinus sylvestris. (d) Cross-section of tree sample GI3, with fire scars indicated by arrows (a-c: S. Alleaume; d: G. Magne).

Holocene, the period covering the last 500 years, charcoal records may be compared with dendrochronological and observational records of fires, if these are available in the study areas (Brossier et al., 2014; Waito et al., 2018). Validation of lacustrine charcoal peaks with tree-ring records has been carried out previously in boreal regions affected by crown fires (e.g. Brossier et al., 2014; Lynch et al., 2004), but to a much lesser degree in landscapes affected by surface fires (Leys et al., 2017).

We propose that because of the small amounts of fuel burned during typical fire events in a landscape affected predominantly by surface fires, lacustrine sediments will be subject to a low charcoal deposition. Such low charcoal influx into the sediments may be difficult to detect accurately to decipher the history of surface fires, calling for a dedicated calibration effort. In this context, the dendrochronology method using fire scars appears as the most efficient technique to accurately reconstruct fire history in such landscapes (Drobyshev et al., 2008; Niklasson and Granstrom, 2000).

The objective of this study was to calibrate recent charcoal peaks from lacustrine deposits in a European boreal landscape against independent dendrochronologically reconstructed fire events. The natural disturbance regime of this landscape has been dominated by fires of different severity, most of the events likely being surface fires (Van Wagner, 1983). To evaluate how alternative proxies of past fire activity differ in respect to their capacity to detect surface fires, we explored the number, surface area, and estimated volume of charcoal particles obtained from lake sediments (Ali et al., 2009). Since we expected low charcoal accumulation rates, we used two different sediment volumes ( 1 and 3.5 $\mathrm{cm}^{3}$ ) to evaluate whether increasing effort affected our ability to correctly estimate charcoal concentration in the sediments (Carcaillet et al., 2001). This study was conducted on two nearby lakes with similar characteristics (topography, surface, water depth). Our initial assumption was that the two lakes would receive an influx of charcoal particles generated by the same fires and that aggregation of data from two lakes would improve the reconstruction accuracy for the landscape in which these lakes were located.

\section{Material and methods}

\section{Study area}

The study area lies in the European middle boreal zone, within the territory of the Kalevala National Park (hereafter KNP), in Republic of Karelia, Northwest Russia. The park, which is $744 \mathrm{~km}^{2}$ in size, was created in 2007 to protect the largest primeval pine forests in Europe (Gromtsev, 2002).

The climate of the area is subarctic (Peel et al., 2007), with long cold winters and short mild summers. The KNP territory is part of the Baltic Shield, a region formed from the Pleistocene glaciation and characterized by numerous (more than 400) lakes. The vegetation is Vaccinium type pine forest (Pinus sylvestris L., Figure 1a-c) with frequent Betula pubescens Ehrh.. The ground vegetation is composed mainly of small shrubs (Vaccinium vitis-idaea L., Vaccinium myrtillus L., Empetrum nigrum L., etc.) and green mosses (Pleurozium schreberi (Brid.) Mitt., Hylocomium splendens (Hedw.) Schimp.). Cladonia lichens dominate the ground cover on open spaces and dry slopes. The gently sloping banks of lakes are covered by small shrubs (Andromeda polifolia L., Ledum palustre L., Empetrum nigrum L., etc.), herbs (Rubus chamaemorus L., Eriophorum vaginatum L., Carex spp.), and Sphagna (Figure 1a-c).

We sampled lacustrine sediments from two lakes: Gingko and Laure (unofficial names, Figure 2). These lakes were chosen because of their proximity to each other (about $170 \mathrm{~m}$ between the nearest shorelines) and similar environmental characteristics (Table 1).

\section{Sampling for dendrochronological reconstruction}

The field sampling was carried out in August 2015. We used a chainsaw to extract partial or full cross-sections (Figure 1d) of fire-scarred live or dead Scots pines (Pinus sylvestris), with a potential lifespan extending over several centuries, which makes this species a useful tree for dendrochronology (e.g. Drobyshev et al., 2014; Helama et al., 2002). Sampled trees were located within $200 \mathrm{~m}$ from the lakeshores to ensure the sampled trees captured the local fires (Figure 2). The cuts were done at the root collar to obtain the longest possible tree-ring chronologies and 


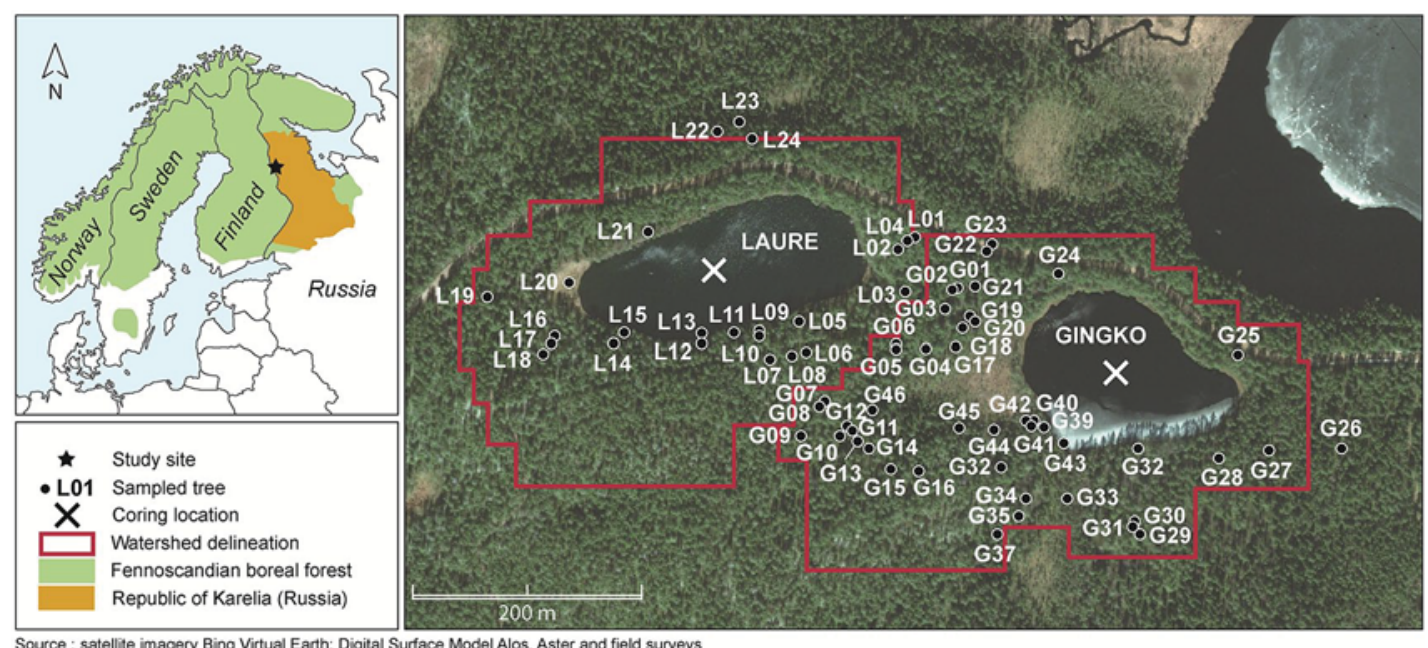

Figure 2. Location of lakes and trees sampled in Kalevala National Park (Republic of Karelia, Russia).Watershed data (in red) were calculated using ArcGis 10.5 software and the Spatial Analyst extension. Three altitude data were used: field surveys (made in 2015 with a GPS Trimble Juno SB, 10 m vertical resolution), and two Global Digital Surface Model with the same horizontal resolution (30 m):ALOS (height accuracy: 5 $\mathrm{m}$, product of JAXA) and ASTER (height accuracy: 7-14 m, product of METI and NASA).

Table I. Location and characteristics of sampled lakes.

\begin{tabular}{|c|c|c|}
\hline Location properties & Gingko & Laure \\
\hline Latitude of the sampling point & $65^{\circ} 0143.9 \mathrm{~N}$ & $65^{\circ} 0147.1 \mathrm{~N}$ \\
\hline $\begin{array}{l}\text { Longitude of the sampling } \\
\text { point }\end{array}$ & $30^{\circ} 2230.6 \mathrm{E}$ & $30^{\circ} 2201.7 \mathrm{E}$ \\
\hline Elevation (m a.s.I.) & 111.8 & 111.9 \\
\hline $\begin{array}{l}\text { Average altitude of the } \\
\text { watershed ( } m \text { a.s.l. })\end{array}$ & 122.0 & 125.9 \\
\hline $\begin{array}{l}\text { Average slope of the } \\
\text { watershed (degrees) }\end{array}$ & 5.9 & 7.2 \\
\hline $\begin{array}{l}\text { Maximum slope of the } \\
\text { watershed (degrees) }\end{array}$ & 14 & 17 \\
\hline Lake surface (ha) & 1.90 & 2.12 \\
\hline Maximum water depth $(\mathrm{m})$ & 6.5 & 8.5 \\
\hline Sampled sequence length $(\mathrm{cm})$ & 28.5 & 37 \\
\hline
\end{tabular}

maximize their overlap with the lacustrine records. We took 46 cross-sections around Lake Gingko and 24 around Lake Laure, and recorded coordinates and scar orientation on sampled trees. Our interest in scar orientation was due to the fact that the direction of the flame movement commonly follows the scar direction (Arno et al., 1977; Dickinson and Johnson, 2001).

Cross-sections were dried and sanded using sandpaper of successively finer grades (P80-P600) until annual growth rings and scars were clearly visible. We dated samples using a binocular microscope according to standard dendrochronological methods (Stokes and Smiley, 1968). Pointer years (Schweingruber et al., 1990), that is, consistently narrow, wide, or rings with otherwise peculiar appearance were identified and used for crossdating. Tree-ring widths were measured using a LINTAB $5 \mu \mathrm{m}$ (Rinn, 2004) with $0.001 \mathrm{~mm}$ precision. Fire scars were identified by their morphological characteristics (Falk et al., 2011) and dated with annual resolution. Crossdating of the tree-ring series was done with TSAPWin 4.64 software (Rinn, 2003) and validated by comparison with chronology RUSS121 of the Schweingruber treering collection (Schweingruber, 2007), developed for a location about $64 \mathrm{~km}$ southeast of our study site.

\section{Sediment sampling and age-depth model}

To focus on the recent fire history, we only collected the uppermost $30 \mathrm{~cm}$ of sediments, using a Kajak-Brinkhurst (KB) gravity corer (Glew, 1989). In the field, the sequences were sliced into continuous 0.5 -cm-thick sub-samples. Sediment accumulation chronologies were based on bulk gyttja samples. For each lake, we used both ${ }^{210} \mathrm{~Pb}$ (gamma) and ${ }^{14} \mathrm{C}$ (AMS) dating to build the age-depth models (Table 2). The dates were obtained by the Radiochronology Laboratory of the Centre for Nordic Studies (Laval University, Canada). The dates were calibrated using the CLAM 2.2 program based on the IntCal13.14C (Hua et al., 2013). The CRS model (Appleby and Oldfield, 1978) was used with ${ }^{210} \mathrm{~Pb}$ dates to determine the age of the sediments for the first 25 $\mathrm{cm}$. This model assumes a constant rate of supply of unsupported ${ }^{210} \mathrm{~Pb}$ to the sediment surface despite variable sediment accumulation rates. The final lake-specific age-depth models were based on both ${ }^{210} \mathrm{~Pb}$ and ${ }^{14} \mathrm{C}$ dating and were obtained using a smoothing spline method (Blaauw, 2010) with CLAM 2.2.

\section{Charcoal particle analysis from lacustrine sediments}

For each 0.5 -cm-thick slice, we took two separate sub-samples of 1 and $3.5 \mathrm{~cm}^{3}$ and shook them for $24 \mathrm{~h}$ in an aqueous solution of $5 \% \mathrm{Na}_{6} \mathrm{O}_{18} \mathrm{P}_{6}, 5 \% \mathrm{KOH}$ and $10 \% \mathrm{NaCl}$ to facilitate deflocculation and to differentiate between black charcoal and bleached organic matter (Bamber, 1982; Schlachter and Horn, 2010). The solution was then passed through a sieve to collect charcoal particles larger than $160 \mu \mathrm{m}$ (Ali et al., 2009), assumed to originate during local fire events, that is, up to $1 \mathrm{~km}$ away from the lakeshores (Higuera et al., 2007). We considered the long-distance transport (from more than $1 \mathrm{~km}$ away) of macroscopic charcoal as an unlikely pathway to reach the sediments, as most of such charcoal is deposited at a short distance $(<50 \mathrm{~m})$ from the fire (Pisaric, 2002; Tinner et al., 2006). Charcoal particles were measured and counted using an image-analysis software (WinSEEDLE, Regent Instruments Inc.) and transformed into charcoal accumulation rates (hereafter CHAR) using the sediment accumulation rates derived from the age-depth models. We were aware of the possibility of taphonomic biases affecting the charcoal production and sequestration, decreasing their number, for example, with particle transport or fragmentation because of charcoal fragility in the sediment (Mustaphi et al., 2015; Oris et al., 2014; Whitlock and Millspaugh, 1996). To remove these biases and minimize variations in sedimentation rates, we interpolated individual CHAR series to the median sample resolution for the last 500 years. We identified local fire events in CHAR series by using CharAnalysis 1.1 software (Higuera et al., 2009). 
Table 2. ${ }^{14} \mathrm{C}$ and ${ }^{210} \mathrm{~Pb}$ dates of Gingko and Laure lakes (Republic of Karelia, Russia).

\begin{tabular}{|c|c|c|c|c|}
\hline \multicolumn{5}{|l|}{ Gingko } \\
\hline${ }^{210} \mathrm{~Pb}$ sample & Depth interval $(\mathrm{cm})$ & ${ }^{210} \mathrm{~Pb}$ activity $(\mathrm{Bq} / \mathrm{g})$ & Age (yr BP) & Use for age-depth model \\
\hline KA_I & $0-2$ & 0.884032 & -29.2087 & Yes \\
\hline KA_2 & $3-5$ & 0.290355 & 9.9685 & Yes \\
\hline KA_3 & $6-7.5$ & 0.058055 & 30.7934 & Yes \\
\hline KA_4 & $9-10.5$ & 0.028749 & 50.1344 & Yes \\
\hline KA_5 & $12-13.5$ & 0.009548 & 60.4375 & Yes \\
\hline KA_6 & $15-16.5$ & 0.012331 & 81.9713 & Yes \\
\hline KA_7 & $18-19.5$ & 0.012905 & $\mathrm{n} / \mathrm{a}$ & No \\
\hline KA_8 & $21-22.5$ & 0.000000 & $\mathrm{n} / \mathrm{a}$ & No \\
\hline${ }^{14} \mathrm{C}$ sample (ID code) & Depth interval $(\mathrm{cm})$ & Sample mass (g) & Age (yr BP) & Use for age-depth model \\
\hline ULA-7268 & $26-27$ & 0.619 & $1560 \pm 15$ & Yes \\
\hline \multicolumn{5}{|l|}{ Laure } \\
\hline${ }^{210} \mathrm{~Pb}$ sample & Depth interval $(\mathrm{cm})$ & ${ }^{210} \mathrm{~Pb}$ activity $(\mathrm{Bq} / \mathrm{g})$ & Age (yr BP) & Use for age-depth model \\
\hline KB_l & $0-2$ & 0.580542 & -27.3255 & Yes \\
\hline KB_2 & $4-5.5$ & 0.102804 & $-|0.017|$ & Yes \\
\hline KB_3 & $7.5-9$ & 0.073767 & 13.0594 & Yes \\
\hline KB_4 & $11-13$ & 0.039244 & 39.3856 & Yes \\
\hline KB_5 & $15.5-17$ & 0.018472 & 68.6368 & Yes \\
\hline KB_6 & $20-21.5$ & 0.024922 & 85.5173 & Yes \\
\hline KB_7 & $24-25.5$ & 0.001507 & 92.8942 & Yes \\
\hline KB_8 & $28-29.5$ & 0.005836 & $\mathrm{n} / \mathrm{a}$ & No \\
\hline${ }^{14} \mathrm{C}$ sample (ID code) & Depth interval $(\mathrm{cm})$ & Sample mass (g) & Age (yr BP) & Use for age-depth model \\
\hline ULA-7267 & $34.5-35.5$ & 0.524 & $2725 \pm 20$ & Yes \\
\hline
\end{tabular}

n/a: non-applicable data.

We used three metrics to evaluate the potential of surface fire to be detected in CHAR series: number $\left(\mathrm{N}_{\text {char }}\right)$, surface area $\left(\mathrm{S}_{\text {char }}\right)$, and estimated volume $\left(\mathrm{V}_{\text {char }}\right)$ of charcoals particles. $\mathrm{V}_{\text {char }}$ was calculated with Weng's (2005) equation:

$$
\mathrm{V}_{\text {char }}=\sum \mathrm{A}_{\mathrm{i}}^{3 / 2}
$$

where $A_{i}$ is the surface area $\left(\mathrm{mm}^{2}\right)$ of each charcoal particle $i$ in a sub-sample. This method was used by Ali et al. (2009) to compare reconstructions of fire histories in coniferous boreal forest of Quebec (Canada), but not in forests dominated by surface fires with potentially low charcoal concentration in sediments. A Kolmogorov-Smirnov test was used to evaluate the significance of differences among fire return intervals (FRIs) obtained using different metrics. Fire events determined by charcoal analysis were associated with the closest fire date (with limits of the sediment accumulation rates), as recorded by dendrochronological dating of fire scars on pine trees, in order to validate these events with certified fire dates.

\section{Results}

\section{Age-depth models}

The sequences from Gingko and Laure lakes were characterized by profiles consisting entirely of bulk gytjia (Table 2 ). The dates of samples KA_7, KA_8, KB_7, and KB_8 were not used because of their low ${ }^{210} \mathrm{~Pb}$ activity $(\mathrm{Bq} / \mathrm{g})$ : this isotope has a half-life of 22.23 years and is not accurate beyond 120 years (Swarzenski, 2014). CRS model and ${ }^{14} \mathrm{C}$ dating helped develop age-depth models (Figure 3), reaching median resolution of 10 and 11.03 years per $0.5 \mathrm{~cm}$ for Gingko and Laure, respectively. The mean resolution of the sediment accumulation rate was 32.61 years per $0.5 \mathrm{~cm}$ for Gingko, and 26.74 years for Laure. For Gingko, the minimum resolution is 1.64 years per $0.5 \mathrm{~cm}$ and the maximum is 115.66 years. For Laure, the minimum resolution is 13.17 years per 0.5 $\mathrm{cm}$ and the maximum is 135.46 years. Sediment accumulation rates were very high at the tops of the cores due to the unconsolidated nature of the sediment. This close proximity of dates between samples within the upper part induced a 'hockey stick' in the age-depth models, and it was particularly visible for Lake Laure.

\section{Fire history reconstructed through fire scar dating}

Wildfires frequently affected the study area over the last 500 years (Figure 4). We dated 148 fire scars and identified 12 single fire years. We considered a year as a fire year if a minimum of three trees had scars dated to the year in question. During the period AD 1570-1836, the mean FRI was 27 years and it declined to 117 years for the period 1836-2015. Fires in 1652, 1678, and 1750 might have been more severe than in other years since they were followed by the establishment of new cohorts of trees.

To better compare fire dates obtained with dendrochronology and charcoal analysis, we identified 'major fires' years, that is, years when the $50 \%$ of all trees recording the year in question was scarred (Figure 4) and fires initiated establishment of a new tree cohort. We identified seven such years: AD 1570, 1632, 1652, $1678,1730,1750$, and 1836 . Of the five remaining fire dates, less than $25 \%$ of trees burned. The spatial pattern of some scarred trees was extremely localized, for example, for 1953, when a fire burned just three trees a few meters from each other (possibly by a human campfire). Fire direction was not informative (Figure 4), probably because of microtopography and because trees have several scars (the first scar influences the following ones because it causes a weakness in the trunk). In addition, the studied lakes are isolated to the west and south by a larger lake (Ozero Zadneye) and located not far from the Ozero Verkhneye Kuyto which 

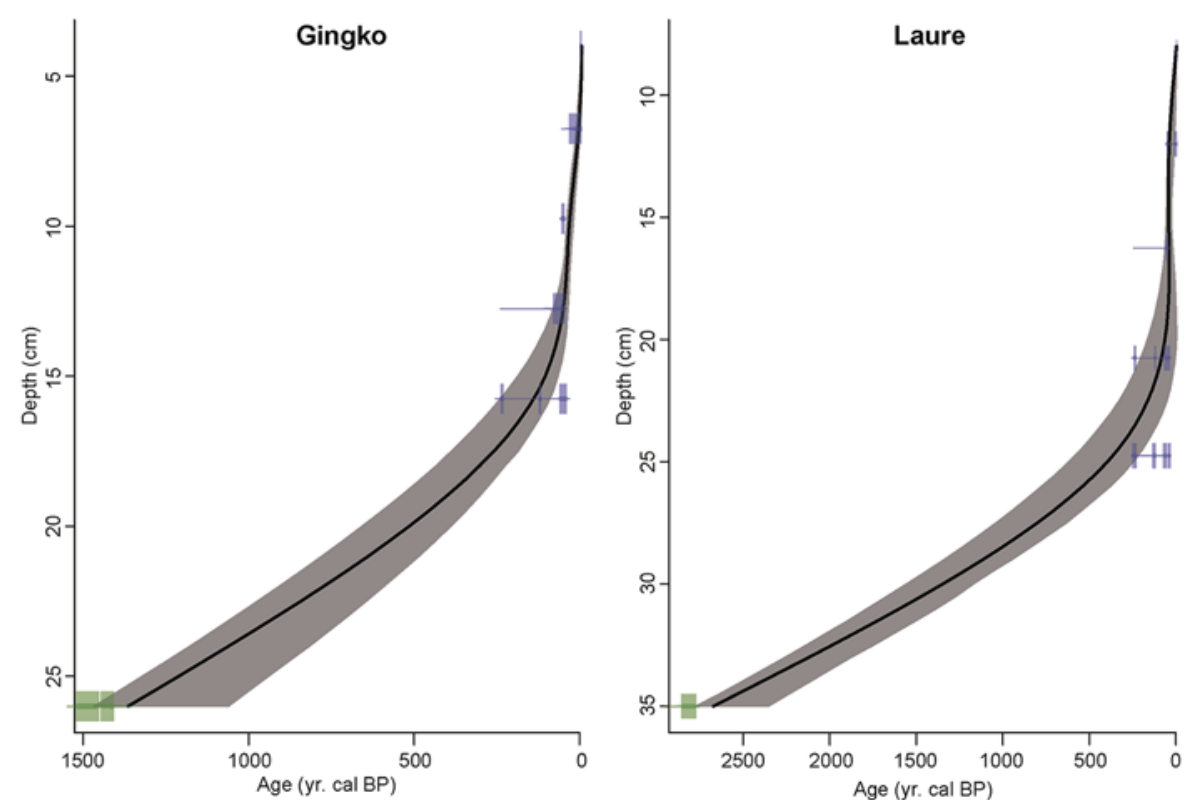

Figure 3. Age-depth models for Gingko and Laure lakes, realized with a CRS model (in blue) and one I4C AMS date at the base of each sampled sequence (in green).

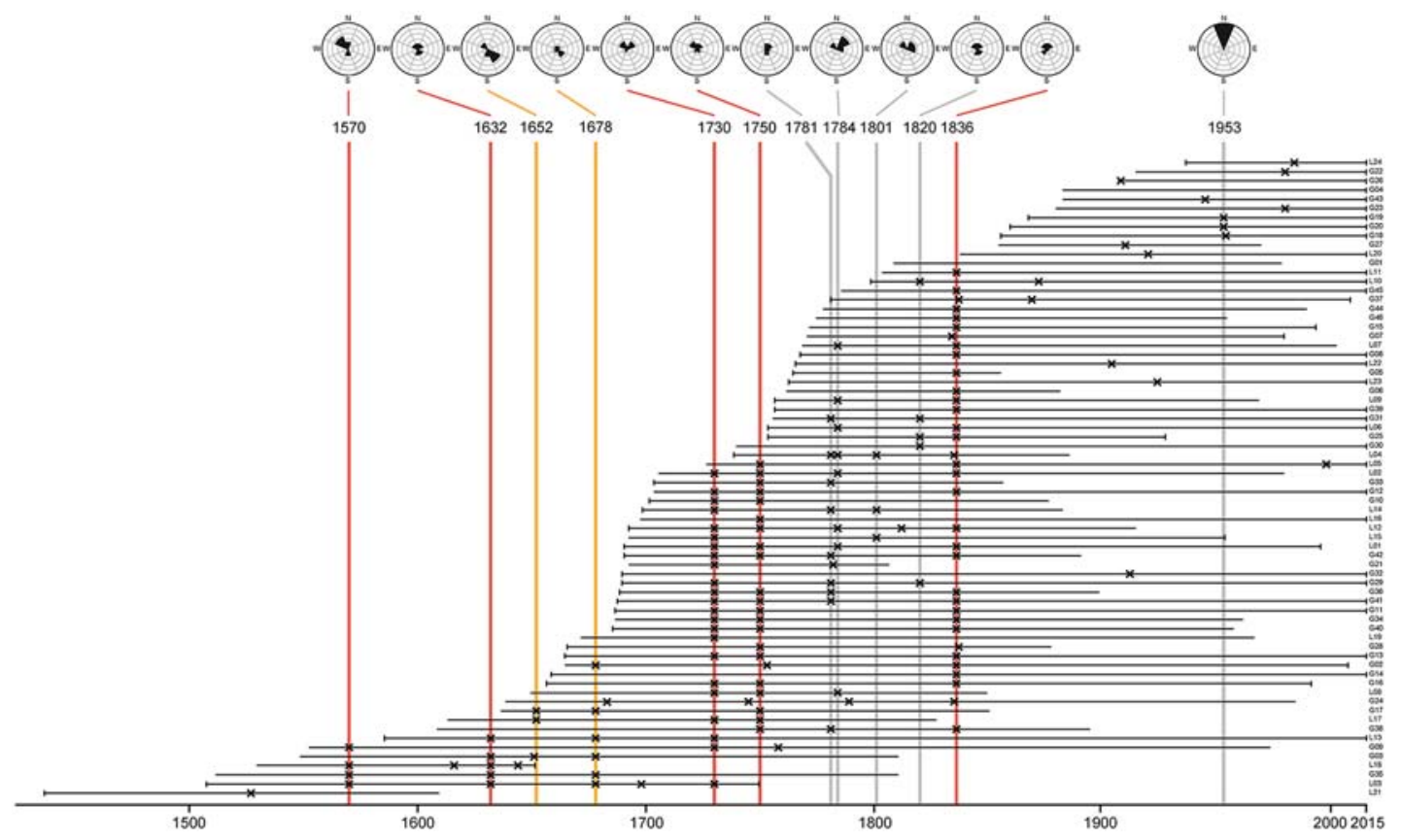

Figure 4. Dendrochronological reconstruction of fire activity around the sampled lakes in KNP. Each horizontal line is an individual tree with its ID indicated on the right-hand side of the graph. Bars around these records to the left or right indicate that the date of birth and death of tree are known, their absence meaning that tree was damaged and a number of tree-rings close to the pith were missing. Black crosses are fire scars and fire dates are classified into three groups according to the percentage of trees burned $(<25 \%$ in gray, $25-50 \%$ in yellow, and $50-75 \%$ in red). Direction of fire front movement is presented in polar plots, each circular graduation corresponding to $20 \%$ of the samples.

could constitute a barrier for wildfires, blurring the orientation of the fire scars.

\section{Charcoal particle concentration and inferred fire histories from lake sediments}

For Gingko, we took 57 sub-samples of $1 \mathrm{~cm}^{3}$ and 57 sub-samples of $3.5 \mathrm{~cm}^{3}$ for charcoal analyses (Figure 5). A total of 25 samples (44\%) contained charcoal particles in the $1 \mathrm{~cm}^{3}$ sub-sample, and 50 samples $(88 \%)$ in $3.5 \mathrm{~cm}^{3}$, and the highest charcoal particle concentrations were 7 and 6 particles, respectively. For Laure, we took 74 sub-samples of $1 \mathrm{~cm}^{3}$ and 74 sub-samples of $3.5 \mathrm{~cm}^{3}$. 46 samples $(62 \%)$ contained charcoals particles in the $1 \mathrm{~cm}^{3}$ sub-sample, and 65 samples $(88 \%)$ in $3.5 \mathrm{~cm}^{3}$, and the highest charcoal particle concentrations were 7 and 14 particles, respectively. There was no significant difference between the 1 and 3.5 $\mathrm{cm}^{3}$ samples for Lake Gingko (Pearson correlation coefficient, $r=0.008, p$ value $=0.955)$; however, it was significant for Lake Laure $(r=0.548, p$ value $<0.001)$.

Charcoal records detected 7-9 fires for Gingko and 9-13 fires for Laure (Figure 6). The median FRI of 68-20.5 years (Table 3) corresponds to the expected FRI in the European boreal forest (Drobyshev et al., 2014; Rolstad et al., 2017). A KolmogorovSmirnov test found no significant difference between the median FRI values obtained with the different metrics $(p$ value $=0.883)$ nor with the mean FRI values ( $p$ value $=0.833$ ). Lacustrine 
records suggested that the fire frequency before AD 1900 averaged at one event every 580 years, while this frequency was very high after 1900: on average, one event every 34 years for Gingko, and one event every 20 years for Laure. In other words, relying exclusively on the lacustrine records one could conclude that frequency of fires has increased 17 and 29 times, for Gingko and Laure respectively, after 1900.

The impact of water concentrations in the sediment was tested, since a high concentration of water in surface sediments can minimize the number of charcoal particles (Mustaphi et al., 2015). However, this correction did not significantly change the results (data not presented).

\section{Comparison between charcoal records and dendrochronological data}

Fire events obtained by lacustrine charcoal records were matched with 10 and 6 dates of fire scars, for lakes Gingko and Laure,
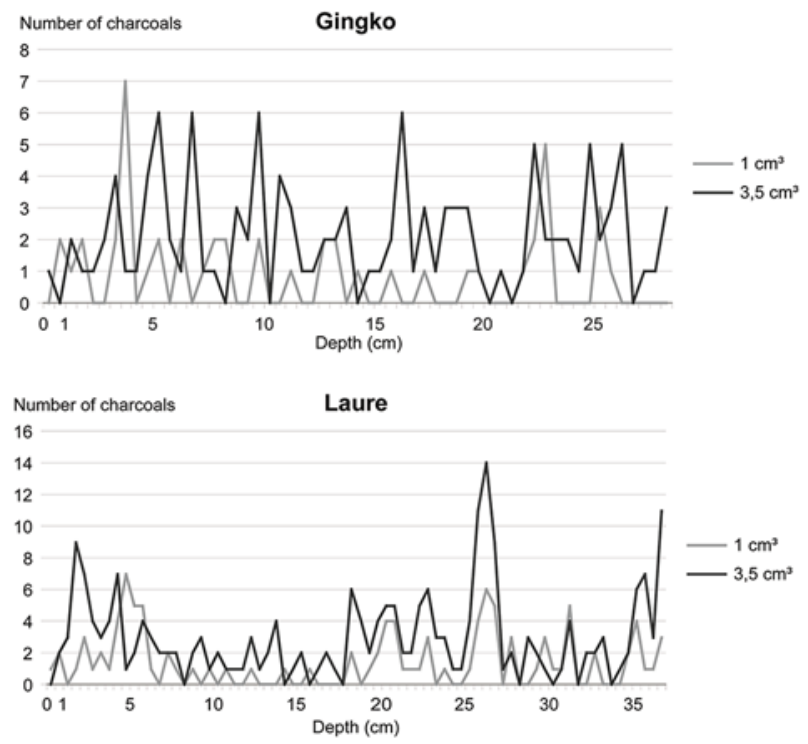

Figure 5. Comparison of the number of charcoal fragments in samples of different volume, for Gingko and Laure lakes. respectively (Figure 7), which corresponded to $83 \%$ and $50 \%$ of all fires reconstructed by dendrochronological method for these lakes. Considering only 'major fires', the corresponding values were $86 \%$ and $71 \%$. Only one fire date (AD 1652) was not detected by any of the metrics used. On average, $37 \%$ of all events reconstructed from lake sediments events did not correspond to any fire dates identified by the dendrochronological analysis for Lake Gingko, and $48.5 \%$ for Lake Laure. These 'false fire events' were only observed in the recent period, since around AD 1950.

The fire records from the studied two lakes differed. For example, the 1750 fire date is only observed with charcoal records of Laure, and 1836 only with charcoal records of Gingko. The composite charcoal record (based on data from both lakes) identified six out of seven 'major fires' reconstructed with the dendrochronological method. For Lake Gingko, we observed the highest correspondence between paleo and dendrochronological records with samples of $1 \mathrm{~cm}^{3}$, and for Lake Laure - with $3.5 \mathrm{~cm}^{3} \mathrm{sam}-$ ples. For Lake Gingko, analysis of $3.5 \mathrm{~cm}^{3}$ samples detected two more valid fire dates than the $1 \mathrm{~cm}^{3}$ samples (i.e. 1953 and 1678), but not AD 1836 and 1570. Similarly, for Lake Laure, the analysis of $3.5 \mathrm{~cm}^{3}$ samples detected only one more fire date (i.e. 1632), but not AD 1730 detected using only $1 \mathrm{~cm}^{3}$ samples.

In both cases, the choice of metric $\left(\mathrm{N}_{\text {char, }}, \mathrm{S}_{\text {char }}\right.$, and $\left.\mathrm{V}_{\text {char }}\right)$ had no real impact on CHAR computation. It is possible that the use of other parameters could change and refine the reconstruction. For example, the fire date AD 1652 was identified in Lake Gingko when we used the 95 percentile of $\mathrm{C}_{\text {noise }}$ distribution as threshold (gray points on Figure 6, panel with the results from $3.5 \mathrm{~cm}^{3} \mathrm{sam}$ ples), but not 99.99 percentile. However, we used the 99.99 percentile, as this is more robust and commonly used in earlier studies (Ali et al., 2009; Higuera et al., 2010).

\section{Discussion}

\section{Variability in concentration of charcoal particles}

Our results suggest that even small concentrations and a very low number of charcoal particles may be indicative of local fires. In this study, the charcoal concentration was $0-7$ particles in $1 \mathrm{~cm}^{3}$ (Figure 5), while the number of charcoal particles found in sediments receiving influx from crown fires usually ranges between 20 and 100 per $\mathrm{cm}^{3}$ (Ali et al., 2009; Brossier et al., 2014; Higuera
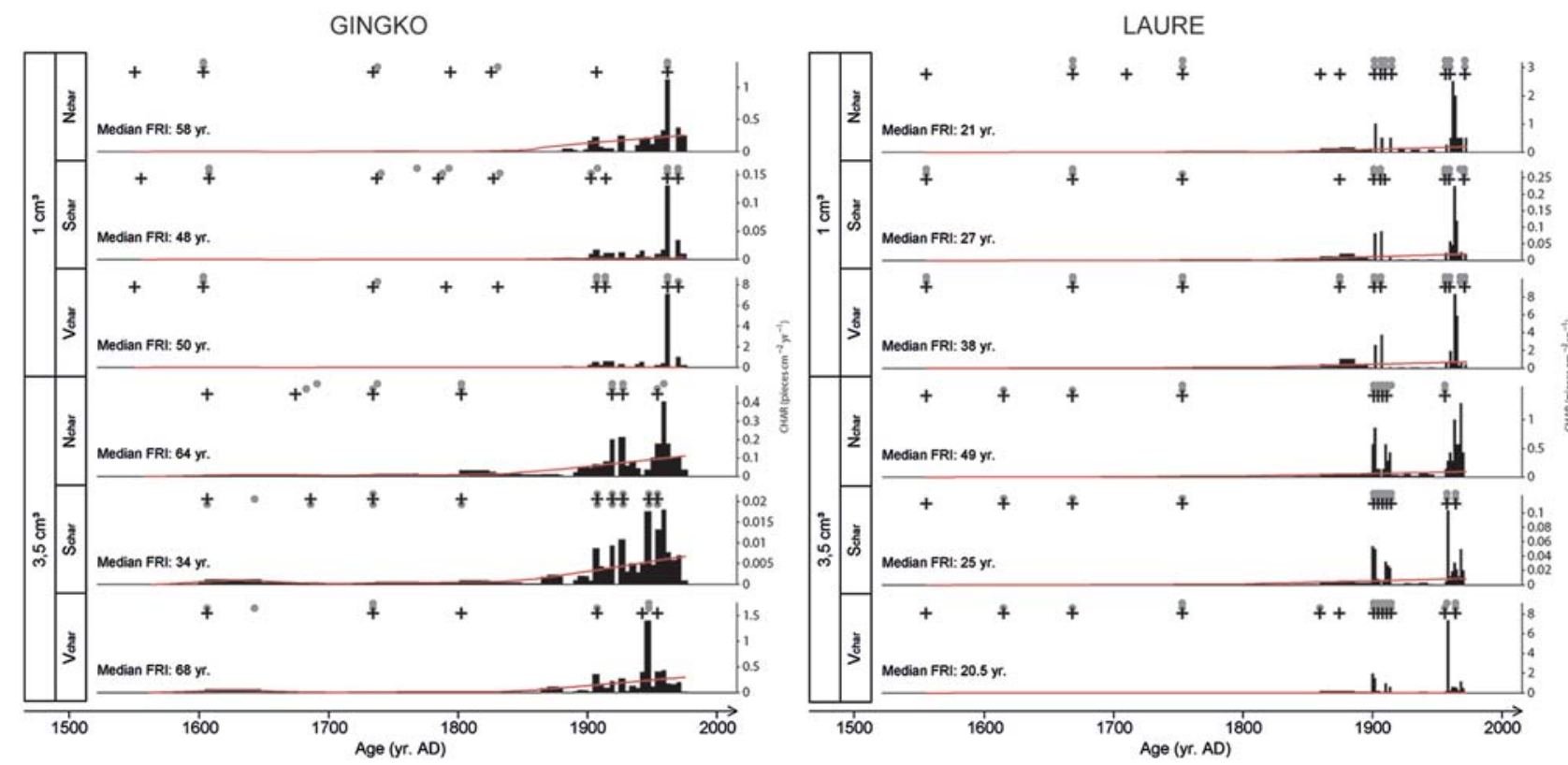

Figure 6. Charcoal records for Gingko and Laure lakes, including CHAR series (in black), background of charcoals influx (in red), and reconstructed fire events ('+' symbols). 
Table 3. Fire return interval (FRI) with lacustrine charcoal analysis, for Gingko and Laure Lakes.

\begin{tabular}{|c|c|c|c|c|c|c|c|c|c|c|c|c|}
\hline \multirow[t]{3}{*}{ FRI } & \multicolumn{6}{|c|}{ Gingko } & \multicolumn{6}{|l|}{ Laure } \\
\hline & \multicolumn{3}{|l|}{$1 \mathrm{~cm}^{3}$} & \multicolumn{3}{|c|}{$3.5 \mathrm{~cm}^{3}$} & \multicolumn{3}{|l|}{$1 \mathrm{~cm}^{3}$} & \multicolumn{3}{|c|}{$3.5 \mathrm{~cm}^{3}$} \\
\hline & $N_{\text {char }}$ & $\mathrm{S}_{\text {char }}$ & $\mathrm{V}_{\text {char }}$ & $\mathrm{N}_{\text {char }}$ & $\mathrm{S}_{\text {char }}$ & $\mathrm{V}_{\text {char }}$ & $\mathrm{N}_{\text {char }}$ & $\mathrm{S}_{\text {char }}$ & $\mathrm{V}_{\text {char }}$ & $\mathrm{N}_{\text {char }}$ & $\mathrm{S}_{\text {char }}$ & $\mathrm{V}_{\text {char }}$ \\
\hline Minimum (year) & 32 & 8 & 8 & 8 & 8 & 12 & 3 & 3 & 4 & 3 & 3 & 3 \\
\hline Maximum (year) & 132 & 132 & 132 & 116 & 104 & 128 & 114 & $|2|$ & 121 & 147 & 147 & 106 \\
\hline Median (year) & 58 & 48 & 50 & 64 & 34 & 68 & 21 & 27 & 38 & 49 & 25 & 20.5 \\
\hline Mean (year) & 68.7 & 52.5 & 52.5 & 58 & 43.5 & 69.6 & 34.7 & 46.2 & 52 & 50.1 & 40.9 & 34.1 \\
\hline
\end{tabular}

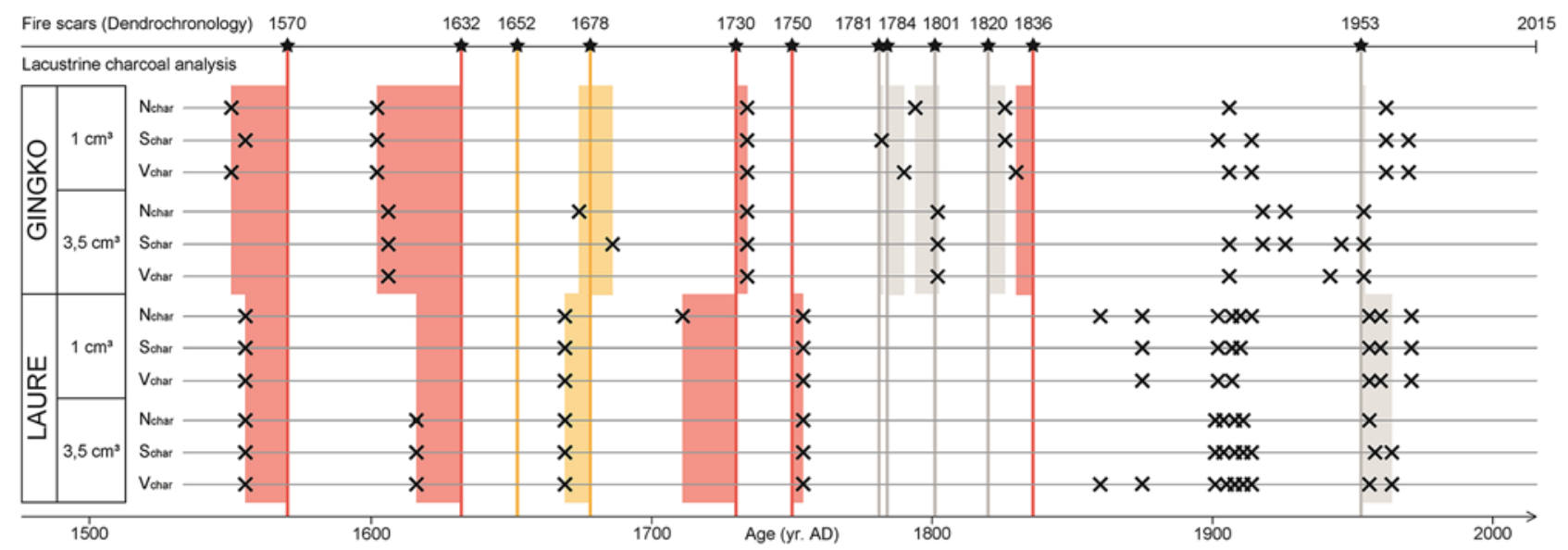

Figure 7. Summary of fire dates obtained with dendrochronology and different methods of charcoals particles analysis (different volumes of sediment used, and use of number Nchar, surface area Schar or estimated volume Vchar of charcoal particles) over the period covered by dendrochronology (last 500 years). Fire events determined by charcoal analysis were associated with the closest fire date (recorded by dendrochronology) if they were included in the temporal error of sample dating. Fire dates are classified according to the percentage of trees burned ( $<25 \%$ in gray, $25-50 \%$ in yellow and $50-75 \%$ in red).

et al., 2010; Remy et al., 2018). The observed pattern is consistent with the idea that boreal surface fires are characterized by a low accumulation of charcoal in the lake sediments. Two factors could explain such low charcoal concentration: (a) a low charcoal production during the fire due to a low amount of biomass burned (Rowe and Scotter, 1973), and (b) poor conservation of herbaceous charcoal produced by surface fires, which is more fragile than charcoal produced by burning wood (Leys et al., 2013, 2017; Mustaphi and Pisaric, 2014).

Although we expected that a low background influx of charcoal would facilitate detection of past fires, a small number of charcoal particles make detection of fire events difficult (Higuera et al., 2010). In part, such difficulty was because of high variability in charcoal concentrations within the sediments sampled at the same depth. At some depths, we found more charcoal particles in $1 \mathrm{~cm}^{3}$ than in $3.5 \mathrm{~cm}^{3}$ sub-samples (Figure 5). This pattern was present in the data from Lake Gingko, where the correlation between number of particles in 1 and $3.5 \mathrm{~cm}^{3}$ was not significant. In Lake Laure, charcoal particles were homogeneously incorporated into the sediment, as a larger volume of sediment often contained more charcoal particles than a smaller volumes, indicating a better fire reconstruction. Variability of charcoal concentration in the sediments calls for exercising caution in the interpretation of palaeofire reconstructions, especially those based on data from a single lake.

\section{Fire history reconstruction}

The results show that palaeofire reconstructions obtained with fossil charcoal data from lake sediments and dendrochronology are similar. Charcoal analysis detected 11 out of the 12 fire dates reconstructed by fire scar dating (Figure 7), and 6 out of 7 if we focus on major fires. Nevertheless, unlike dendrochronology with its annual precision, palaeofire reconstructions with charcoal analysis is limited by the inaccuracy of the age-model. Even if the accuracy is less (median resolution of 10 and 11.03 years per 0.5 $\mathrm{cm}$ for Gingko and Laure, respectively), lacustrine charcoal analysis can however reconstruct the major trends and fire dynamics of past times.

The use of different sediment volumes yielded fairly similar results when fire dates deduced from charcoal analysis of dated lake sediments were compared with the dates of fire scars. While using $1 \mathrm{~cm}^{3}$ samples, we correctly dated five or six major fires, which corresponded to $71 \%$ and $86 \%$ of all major fire dates already known from dendrochronological reconstruction. Using $3.5 \mathrm{~cm}^{3}$ samples, we detected five such fires $(71 \%$ of major fire dates). This result indicated that using $1 \mathrm{~cm}^{3}$ of sediment is sufficient for fire reconstruction, making analysis of samples of a larger volume redundant, when the sediment is homogeneous.

No lacustrine charcoal metric seems to stand out from the others, all allowing us to detect overall the same major fire events. Similarly, the use of different metrics did not significantly influence the reconstructed FRI (Table 3). However, the use of replicates (intra-sample and inter-lake) seems to be of importance to fully establish a representative fire history from lacustrine charcoal particles. This protocol is obviously time-consuming but it must be followed if the goal is to maximize the skill of detectioning surface fires.

The comparison of two lakes revealed a large variability in the reconstructed fire record, despite the fact that these were only $170 \mathrm{~m}$ apart. Environmental conditions (e.g. wind direction, size of fire, runoff direction, precipitation) could alter the recording of a fire event in lacustrine sediments (Oris et al., 2014; Remy et al., 2018). The use of a single lacustrine sequence is not 
sufficient for reconstruction of the local fire history, and it is important to study several lakes to arrive at a more regional record of fire history.

\section{Problem of 'false fire events' in the recent period (1836-20/5)}

Fire reconstruction from the upper section of the sediments of Lake Laure indicated fire events, which were not present in the dendrochronological records. These 'false events' could be explained by re-mobilization of charcoal particles sequestered in the soils following earlier fire events might contribute to charcoal influx during the years with no fires. This could be related to the latency of charcoal sequestration in sediments, as has been demonstrated in other regions (Duffin et al., 2008; Hallett et al., 2003). The long-distance transport of charcoal by wind from distant fires can be dismissed, since we explained previously that the studied charcoals came mainly from local fires.

\section{Conclusion}

Fossil charcoal data from lake sediments can be used to accurately detect fire events in the boreal forests with frequent surface fires. Charcoal records possess therefore a strong potential to complement more precise but shorter dendrochronological records in ecosystems where low severity fires are the dominant element of the natural disturbance regime. The choice of a particular charcoal-based proxy, such as number, surface area, or estimated total volume of charcoal particles, does not have a considerable impact on the reconstruction results, as suggested by our results and those published earlier (Ali et al., 2009). While a volume of $1 \mathrm{~cm}^{3}$ seems sufficient, it is the number of replicates for a depth horizon and the number of lakes sampled that is critical to ensure the reconstruction quality as even two extremely close lakes may exhibit rather contrasting charcoal accumulation records.

\section{Acknowledgements}

We thank Nina Ryzhkova for her help in the field campaign logistics, as well as Sandrine Canal and Chéima Barhoumi for their help with the study of charcoal particles. We thank administration of the Kalevala National Park for the administrative help with the fieldwork. We thank also Colin Courtney-Mustaphi and an anonymous reviewer for providing useful comments and improvements to the manuscript. This is an ISEM contribution No. ISEM 2019-163.

\section{Funding}

The author(s) disclosed receipt of the following financial support for the research, authorship, and/or publication of this article: This research was funded by the Belmont Forum through the Agence Nationale de la Recherche (ANR) as part of the PREREAL international research project (grant 292-2015-11-30-13-43-09 to ID), the Institut Universitaire de France (IUF) to Ali AA, and the state order to the Forest Research Institute of Karelian Research Center Russian Academy of Sciences (FRI KarRC RAS). ID contribution was funded by projects PREFORM, CLIMECO, and BalticFire (\#10066-2017-13 and \#24474/2018 to ID). The study was conducted within the framework of the NordicProxy network, which is supported by the Nordic Forest Research (SNS) and consortium GDRI Cold Forests.

\section{ORCID iD}

Gwenaël Magne iD https://orcid.org/0000-0003-1524-4430

Christelle Hély (iD https://orcid.org/0000-0002-7549-3239

Samuel Alleaume (iD https://orcid.org/0000-0002-9200-8338

\section{References}

Ali AA, Higuera PE, Bergeron Y et al. (2009) Comparing firehistory interpretations based on area, number and estimated volume of macroscopic charcoal in lake sediments. Quaternary Research 72: 462-468.

Appleby PG and Oldfield F (1978) The calculation of Lead-210 dates assuming a constant rate of supply of unsupported $210 \mathrm{~Pb}$ to the sediment. Catena 5: 1-8.

Arno SF, Sneck KM and Forest I (1977) A Method for Determining Fire History in Coniferous Forests of the Mountain West. General technical report INT-42. Ogden, UT: Intermountain Forest and Range Experiment Station, Forest Service, US Department of Agriculture.

Bamber RN (1982) Sodium hexametaphosphate as an aid in benthic sample sorting. Marine Environmental Research 7(4): $251-255$

Blaauw M (2010) Methods and code for 'classical' age-modelling of radiocarbon sequences. Quaternary Geochronology 5: $512-518$

Bowman DM, Balch JK, Artaxo P et al. (2009) Fire in the Earth system. Science 324(5926): 481-484.

Brossier B, Oris F, Finsinger W et al. (2014) Using tree-ring records to calibrate peak detection in fire reconstructions based on sedimentary charcoal records. The Holocene 24(6): 635-645.

Carcaillet C, Bouvier M, Fréchette B et al. (2001) Comparison of pollen-slide and sieving methods in lacustrine charcoal analyses for local and regional fire history. The Holocene 11(4): 467-476.

De Groot WJ, Cantin AS, Flannigan MD et al. (2013) A comparison of Canadian and Russian boreal forest fire regimes. Forest Ecology and Management 294: 23-34.

Dickinson M and Johnson E (2001) Fire effects on trees. In: Johnson EA and Miyanishi K (eds) Forest Fires: Behavior and Ecological Effects. New York: Academic Press, pp. 477-525.

Drobyshev I, Goebel PC, Hix DM et al. (2008) Pre- and postEuropean settlement fire history of red pine dominated forest ecosystems of Seney National Wildlife Refuge, Upper Michigan. Canadian Journal of Forest Research 38(9): 2497-2514.

Drobyshev I, Granström A, Linderholm HW et al. (2014) Multicentury reconstruction of fire activity in Northern European boreal forest suggests differences in regional fire regimes and their sensitivity to climate. Journal of Ecology 102(3): 738-748.

Duffin KI, Gillson L and Willis KJ (2008) Testing the sensitivity of charcoal as an indicator of fire events in savanna environments: Quantitative predictions of fire proximity, area and intensity. The Holocene 18(2): 279-291.

Falk DA, Heyerdahl EK, Brown PM et al. (2011) Multi-scale controls of historical forest-fire regimes: New insights from fire-scar networks. Frontiers in Ecology and the Environment 9: 446-454.

Flannigan M, Stocks BJ, Turetsky M et al. (2008) Impacts of climate change on fire activity and fire management in the circumboreal forest. Global Change Biology 14: 1-12.

Gavin DG, Hallett DJ, Hu FS et al. (2007) Forest fire and climate change in western North America: Insights from sediment charcoal records. Frontiers in Ecology and the Environment 5(9): 499-506.

Glew JR (1989) A new trigger mechanism for sediment samplers. Journal of Paleolimnology 2: 241-243.

Gromtsev AN (2002) Natural Complexes, Flora and Fauna of Proposed 'Kalevala National Park' (The Finnish Environment), vol. 577. Helsinki: Edita Prima Ltd.

Hallett DJ, Mathewes RW and Walker RC (2003) A 1000-year record of forest fire drought and lake-level change in southeastern British Columbia, Canada. The Holocene 13(5): $751-761$ 
Helama S, Lindholm M, Timonen M et al. (2002) The supralong Scots pine tree-ring record for Finnish Lapland: Part 2, interannual to centennial variability in summer temperatures for 7500 years. The Holocene 12(6): 681-687.

Higuera PE, Brubaker LB, Anderson PM et al. (2009) Vegetation mediated the impacts of postglacial climate change on fire regimes in the south-central Brooks Range, Alaska. Ecological Monographs 79(2): 201-219.

Higuera PE, Gavin DG, Bartlein PJ et al. (2010) Peak detection in sediment-charcoal records: Impacts of alternative data analysis methods on fire-history interpretations. International Journal of Wildland Fire 19: 996-1014.

Higuera PE, Peters ME, Brubaker LB et al. (2007) Understanding the origin and analysis of sediment-charcoal records with a simulation model. Quaternary Science Reviews 26(13-14): 1790-1809.

Hua Q, Barbetti M and Rakowski AZ (2013) Atmospheric radiocarbon for the period 1950-2010. Radiocarbon 55(4): 2059-2072.

Leys BA, Commerford JL and McLauchlan KK (2017) Reconstructing grassland fire history using sedimentary charcoal: Considering count, size and shape. PLoS ONE 12(4): e0176445.

Leys BA, Carcaillet C, Dezileau L et al. (2013) A comparison of charcoal measurements for reconstruction of Mediterranean paleo-fire frequency in the mountains of Corsica. Quaternary Research 79(3): 337-349.

Lynch JA, Clark JS and Stocks BJ (2004) Charcoal production, dispersal, and deposition from the Fort Providence experimental fire: Interpreting fire regimes from charcoal records in boreal forests. Canadian Journal of Forest Research 34: 1642-1656.

Mustaphi CJC and Pisaric MFJ (2014) A classification for macroscopic charcoal morphologies found in Holocene lacustrine sediments. Progress in Physical Geography 38(6): 734-754.

Mustaphi CJC, Davis EL, Perreault JT et al. (2015) Spatial variability of recent macroscopic charcoal deposition in a small montane lake and implications for reconstruction of watershedscale fire regimes. Journal of Paleolimnology 54(1): 77-86.

Niklasson M and Granstrom A (2000) Numbers and sizes of fires: Long-term spatially explicit fire history in a Swedish boreal landscape. Ecology 81(6): 1484-1499.

Oris F, Ali AA, Asselin H et al. (2014) Charcoal dispersion and deposition in boreal lakes from 3 years of monitoring: Differences between local and regional fires. Geophysical Research Letters 41: 6743-6752.

Pan Y, Birdsey RA, Fang J et al. (2011) A large and persistent carbon sink in the world's forests. Science 333: 988-993.

Payette S (1992) Fire as a controlling process in the North American boreal forest. In: Shugart HH, Leemans R and Bonan GB (eds) A Systems Analysis of the Global Boreal Forest. Cambridge: Cambridge University Press, pp. 144-169.

Peel MC, Finlayson BL and McMahon TA (2007) Updated world map of the Köppen-Geiger climate classification. Hydrology and Earth System Sciences 11: 1633-1644.

Pisaric MFJ (2002) Long-distance transport of terrestrial plant material by convection resulting from forest fires. Journal of Paleolimnology 28: 349-354.
Remy C, Fouquemberg C, Asselin H et al. (2018) Guidelines for the use and interpretation of palaeofire reconstructions based on various archives and proxies. Quaternary Science Reviews 193: 312-322.

Rinn F (2003) TSAP-Win: Time series Analysis and Presentation for Dendrochronology and Related Applications (Version 0.55 User reference). Heidelberg: RINNTECH.

Rinn F (2004) LINTAB 5: Tree-Ring Measurement Station (Electronic Brochure). Heidelberg: RINNTECH.

Rolstad J, Blanck Y and Storaunet KO (2017) Fire history in a western Fennoscandian boreal forest as influenced by human land use and climate. Ecological Monographs 87(2): 219-245.

Rowe JS and Scotter GW (1973) Fire in the boreal forest. Quaternary Research 3(3): 444-464.

Schlachter KJD and Horn SP (2010) Sample preparation methods and replicability in macroscopic charcoal analysis. Journal of Paleolimnology 44: 701-708.

Schreier SF, Richter A, Schepaschenko D et al. (2015) Differences in satellite-derived NOx emission factors between Eurasian and North American boreal forest fires. Atmospheric Environment 121: 55-65.

Schweingruber FH (2007) Tree-Ring Measurements of Pinus sylvestris (Scotch pine) from Sample KOSTPISY-11. Birmensdorf: Swiss Federal Institute for Forest, Snow and Landscape Research, PANGAEA.

Schweingruber FH, Eckstein D, Serre-Bachet F et al. (1990) Identification, presentation and interpretation of event years and pointer years in dendrochronology. Dendrochronologia 8: 9-38.

Stokes M and Smiley T (1968) An Introduction to Tree-ring Dating. Chicago, IL: University of Chicago Press.

Swarzenski PM (2014) 210Pb dating. In: Rink WJ and Thompson JW (eds) Encyclopedia of Scientific Dating Methods. Dordrecht: Springer, pp. 1-11.

Tinner W, Hofstetter S, Zeugin F et al. (2006) Long-distance transport of macroscopic charcoal by an intensive crown fire in the Swiss Alps - Implications for fire history reconstruction. The Holocene 16(2): 287-292.

Van Wagner CE (1983) Fire behavior in northern coniferous forests. In: Wein RW and MacLean DA (eds) The Role of Fire in Northern Circumpolar Ecosystems (SCOPE). Chichester: John Wiley and Sons, pp. 65-80.

Waito J, Girardin MP, Tardif JC et al. (2018) Recent fire activity in the boreal eastern interior of North America is below that of the past 2000 yr. Ecosphere 9(6): e02287.

Weng C (2005) An improved method for quantifying sedimentary charcoal via a volume proxy. The Holocene 15(2): 298-301.

Whitlock C and Millspaugh SH (1996) Testing the assumptions of fire-history studies: An examination of modern charcoal accumulation in Yellowstone National Park, USA. The Holocene 6(1): 7-15.

Wotton BM, Nock CA and Flannigan MD (2010) Forest fire occurrence and climate change in Canada. International Journal of Wildland Fire 19(3): 253-271. 